\title{
HUBUNGAN KARAKTERISTIK ORANG TUA DENGAN PENGETAHUAN TENTANG FAKTOR RISIKO KANKER PADA ANAK
}

\author{
Nuraini Hakim ${ }^{1}$, Ria Anugrahwati ${ }^{2}$ \\ 1. Dosen Akademi Keperawatan Manggala Husada \\ 2. Dosen Akademi Keperawatan Manggala Husada
}

E-mail: nuraini.hakim85@gmail.com

\begin{abstract}
Abstrak
Kanker adalah sekelompok penyakit yang menyebabkan pertumbuhan dan penyebaran sel abnormal secara berlebihan. Indonesia termasuk negara dengan kasus kanker tinggi yang diderita anak-anak. Orang tua dapat melakukan upaya pencegahan dengan mengenali faktor risiko penyebab kanker. Pencegahan kanker perlu dilakukan untuk menekan jumlah morbiditas dan mortalitas kanker. Upaya yang dilakukan untuk mencegah penyakit kanker salah satunya dengan menghindari faktor risiko pencetus kanker. Tujuan penelitian ini adalah mengetahui hubungan karakteristikorang tua dengan pengetahuan orang tua tentang faktor risiko kanker pada anak. Penelitian ini menggunakan desain deskriptif, dengan menggunakan pendekatan cross sectional. Hasil yang didapatkan dari penelitian ini adalah sebagian besar responden memiliki tingkat pengetahuan cukup baik dan terdapat hubungan antara pendidikan ibu dengan pengetahuan tentang faktor risiko kanker pada anak. Rekomendasi diberikan pada orang tua untuk meningkatkan wawasan mengenai kanker agar meningkatkan pengetahuan serta diharapkan mampu mencegah terjadinya penyakit kanker terutama pada anak.
\end{abstract}

Kata kunci: kanker, faktor risiko kanker, anak dengan kanker

\section{Abstract}

Cancer is a group of diseases that cause the growth and spread of abnormal cells. Indonesia was one of the high cases of cancer afflicting children. Parents can do prevention by recognizing risk factors of cancer. Cancer prevention needs to be done to reduce the amount of morbidity and mortality of cancer. Efforts are being made to prevent cancer by avoiding precipitating risk factors for cancer. The aim of the research are to identified level of parent's knowledge about risk factor of cancer and correlation between its characteristic. The research design using descriptive with cross sectional method. The result of the research are most respondent having quite good of level knowledge about cancer risk factor. There are correlation both education level and knowledge level. The recommendations for parents is to improve knowledge about cancer that can be expected to prevent the occurrence of cancer especially in children.

Keywords: risk factor of cancer, cancer in children 


\section{Pendahuluan}

Kanker adalah sekelompok penyakit yang menyebabkan pertumbuhan dan penyebaran sel abnormal secara berlebihan (Potts dan Mandleco, 2012).Prevalensi kanker menurut Amerian Cancer Society (2017), sebanyak $1 \%$ anak di Amerika Serikat didiagnosa dengan kanker, dan terjadi sedikit peningkatan dalam 2 tahun terakhir.Jumlah kanker di Indonesia menurut Riset Kesehatan Dasar (RISKESDAS) tahun 2013 sebanyak 1,4 permil, namun menurut Setyawan (2017) setiap tahun Komisi Perlindungan Anak Indonesia (KPAI) mencatat sekitar 4.100 kasus kanker baru dengan penderita anakanak Indonesia dan kanker rentan menyerang anak-anak usia sekolah, dengan demikian Indonesia termasuk negara dengan kasus kanker tinggi yang diderita anak-anak.

Penyakit kanker pada anak adalah kondisi yang menyebabkan kehidupan anak dan keluarga mengalami perubahan. Meskipun kemajuan perkembangan penanganan kanker dalam 5 tahun terakhir berkembang dengan baik seiring bertambahnya survival sebanyak $80 \%$, namun tetap menjadikan kanker sebagai penyebab kematian kedua pada anak usia 5-14 tahun (Murphy, Xu, \&Kochanek, 2013). Jenis kanker yang sering terjadi pada anak adalah Acute lymphoblastic leukemia (ALL) (26\%), tumor otak (21\%), neuroblastoma (7\%), dan limfoma non Hodghkin (6\%), tumor Wilms (5\%), acute myeloid leukemia (AML) (5\%), tumor tulang (4\%), limfoma Hodgkin (4\%), rhabdomiosarkoma (3\%), dan retinoblastoma (3\%) (Ward, DeSantis, Robbina, Kohler, \& Jemal, 2014).

Tanda dan gejala pada anak muncul secara tidak spesifik, dan ini dapat menyebabkan lambatnya deteksi kanker yang terjadi. Keterlambatan deteksi dini kanker pada anak, akan mengakibatkan bahaya yang lebih lanjut untuk tubuh anak. Hal ini sejalan dengan pernyataan Stefan dan harif (2017), yang menjelaskan apabila tanda dan gejala kanker dapat dideteksi secara cepat maka dapat meningkatkan survival penderita kanker. Deteksi dini dapat dilakukan dengan memiliki pengetahuan tentang penyakit kanker dan mengenali faktor risiko terhadap kanker pada anak. Orang tua dapat melakukan upaya pencegahan dengan mengenali faktor risiko penyebab kanker. Hal ini sejalan dengan pernyataan Tehuteru (2015) bahwa penyebab kanker secara keseluruhan merupakan berasal dari hal yang mampu dicegah. Pencegahan kanker perlu dilakukan untuk menekan jumlah morbiditas dan mortalitas kanker. Upaya yang dilakukan untuk mencegah penyakit kanker salah 
satunya dengan menghindari faktor risiko pencetus kanker.

Berdasarkan studi pendahuluan yang dilakukan oleh penulis di PAUD wilayah Jakarta Timur, masih sedikit orang tua yang mengetahui faktor risiko pencetus kanker dan upaya pencegahan dengan tepat. Selain itu, belum ditemukan penelitian mengenai tingkat pengetahuan orang tua mengenai faktor risiko kanker pada anak. Berdasarkan uraian tersebut, maka penulis tertarik untuk mengidentifikasi tingkat pengetahuan orang tua tentang faktor risiko kanker pada anak.

\section{Tinjauan Teori}

\section{Pengertian}

Kanker adalah sekumpulan penyakit yang disebabkan oleh bertumbuhnya sel-sel jaringan tubuh yang tidak normal. Sel-sel kanker akan berkembang dengan cepat, tidak terkendali, dan akan terus membelah diri. Selanjutnya, sel kanker akan menyerang ke jaringan sekitarnya dan terus menyebar (metastase) melalui jaringan ikat, darah, limfatik, serta menyerang organ-organ penting dan saraf tulang belakang (Potts dan mandleco, 2012 dan National Cancer Institute, 2015).

\section{Penyebab Kanker}

Penyebab pasti dari kanker tidak ada yang mengetahui secara pasti, namun terdapat beberapa faktor risiko. Faktor risiko yang dapat menyebabkan kanker disebut karsinogen Faktor-faktor tersebutmenurut Wariyah dan Dewi (2013), Botto et al, (2013), Spector, Pankratz, dan Marcotte(2015) antara lain:

a. Senyawa kimia

Zat pengawet, zat pewarna, bahan tambahan pada makanan dan minuman dapat menyebabkan kanker jika dikonsumsi dalam jangka waktu yang lama. Bahan sintetis misalnya bahan dalam industri plastik, bahan industri, bahan celup dan juga obat-obatan kemoterapi di dunia kedokteran. Hasil penelitian yang dilakukan oleh $\mathrm{Yu}$ dkk (2012) dalam Wariyah dan Dewi (2013) didapatkan pada jajanan anak yang menggunakan Borak dan formalin sebagai pengawet, serta sakarin dan sodium siklamat sebagai pemanis buatan dapat menyebabkan terjadinya kanker.

b. Faktor fisika

Faktor fisika dalam hal ini adalah bom atom dan radioterapi agresif(radiasi sinar pengion). Radiasi dapat ditimbulkan oleh gelombang elektromagnetik yang berasal dari sinyal televisi, sinar radar, cahaya tak terlihat, sinar $\mathrm{X}$ dan sinar gamma. Radiasi dosis tinggi dapat berisiko terhadap kanker. Paparan terhadap sinar ultra violet juga turut menjadi faktor penyebab. 
Paparan radiasi sinar-X pada ibu hamil dapat menjadi faktor risiko. Pengaruh paparan handphone dalam jangka panjang dapat memberikan radiasi tinggi dan berisiko menyebabkan kanker otak (WHO (2012) dalam Manarisip, 2015).

c. Virus

Virus yang menjadi penyebab kanker sulit dipastikan karena virus sulituntuk diisolasi. Virus dianggap bisa menyatukan diri dalam strukturgenetik sel, sehingga mengganggu generasi selanjutnya dari populasi tersebut.

\section{e. Kelainan kongenital (birth defect)}

Kelainan sejak lahir yang dimiliki anak seperti sindrom down, kelainan syaraf, seperti spina bifida, hidrosefalus, mikrosefalus, kelainan mata seperti katarak berisiko terjadinya kanker. Selain itu yang menjadi faktor risiko adalah kelainan jantung, labioskizis, palatoskizis, kelaianan saluran pencernaan seperti atresia ani, hirschsprung, dan kelainan pada system urinaria seperti hipospadi dan obstruksi pada saluran perkemihan.

\section{f. Kebiasaan merokok}

Kebiasaan merokok secara langsung oleh orang tua atau perokok pasif dapat menjadikan penyebab kanker.

\section{g. Faktor genetik}

Seseorang yang mempunyai riwayat keluarga dengan kanker payudara akan memperbesar resiko terjadinya kanker dibandingkan dengan orang yang tidak mempunyai faktor resiko tersebut.

Faktor yang Mempengaruhi Pengetahuan

Menurut Erfandi (2009), terdapat beberapa faktor yang mempengaruhi pengetahuan seseorang, yaitu :

a) Pendidikan

Pendidikan adalah upaya untuk pengembangan kepribadian dan kemampuan yang didapat dari dalam dan luar sekolah, berjalan seumur hidup. Pendidikan seseorang akan berpengaruh terhadap proses belajar, harapannya makin tinggi pendidikan seseorang makin mudah orang tersebut untuk menerima informasi. b) Media massa / informasi

Majunya teknologi akan tersedia bermacam-macam media massa yang dapat mempengaruhi pengetahuan masyarakat tentang inovasi baru.

b) Sosial budaya dan ekonomi

Nilai budaya, kebiasaan dan tradisi yang dilakukan oleh individu umumnya tanpa melalui penalaran tentang baik buruknya 
suatu hal. Tingkat ekonomi seseorang dapat pula menjadi penentu menentukan tersedianya suatu fasilitas yang diperlukan untuk kegiatan tertentu, sehingga status sosial ekonomi ini akan mempengaruhi pengetahuan seseorang.

c) Lingkungan

Lingkungan adalah segala sesuatu yang ada di sekitar individu, baik lingkungan fisik, biologis, maupun sosial. Lingkungan berpengaruh terhadap proses masuknya pengetahuan ke dalam individu yang berada dalam lingkungan tersebut.

d) Pengalaman

Pengalaman sebagai sumber pengetahuan adalah suatu cara untuk memperoleh kebenaran pengetahuan dengan melihat kembali kejadian masa lampau. Pengalaman belajar dalam suatu pekerjaan yang dikembangkan memberikan pengetahuan dan keterampilan professional

e) Usia

Usia mempengaruhidaya tangkap dan kemampuanberpikir seseorang.

\section{Metodologi}

Penelitian ini menggunakan desain deskriptif, yaitu penelitian yang bertujuan untuk mengeksplorasi suatu fenomena (Notoadmojo, 2012). Desain ini menggunakan pendekatan cross sectional yang bertujuan mengetahui tingkat pengetahuan orang tua tentang faktor risiko kanker pada anak, dan hubungannya dengan pendidikan, usia, dan pengalaman. orang tua.

\section{Hasil Penelitian}

\section{Karakteristik Ibu dan Anak}

Karakteristik anak meliputi usia, jenis kelamin, dan tingkat sekolah. Karakteristik ibu meliputi usia, pendidikan terakhir, pekerjaan, dan jumlah penghasilan keluarga. Berikut ini gambaran karakteristik anak dan ibu.

Tabel 1.

Distribusi Karakteristik Respoden BerdasarkanPendidikan Terakhir Penghasilan Keluarga, Usialbu, Jenis Kelamin, Usia anak, Kelas, dan Pekerjaan Ibu, di Jakarta Timur $(\mathrm{n}=57)$

\begin{tabular}{lcc}
\hline \multicolumn{1}{c}{ Variabel } & $\mathrm{N}$ & $\%$ \\
\hline 1. Pendidikan Ibu & & \\
a. Pendidikan SD & 4 & 7,07 \\
b. Pendidikan SMP & 12 & 21,05 \\
c. Pendidikan SMA & 31 & 54,38 \\
d. Pendidikan S1 & 10 & 17,5
\end{tabular}

2. Penghasilan Keluarga

$\begin{array}{llcc}\text { a. } & \text { 2-3 juta } & 28 & 49,12 \\ \text { b. Lebih dari 3-4 juta } & 16 & 28 \\ \text { c. lebih dari 4-5 juta } & 6 & 10,5 \\ \text { d. lebih dari 5 juta } & 7 & 12,2\end{array}$

3. Usia Ibu

$\begin{array}{llll}\text { a. 20-30 tahun } & 22 & 38,52 \\ \text { b. } & 31-40 \text { tahun } & 18 & 31,58 \\ \text { c. } 41-50 \text { tahun } & 17 & 29,9\end{array}$

4. Jenis Kelamin

a. Laki-laki $28 \quad 49,12$

b. Perempuan 50,88 


\begin{tabular}{|c|c|c|c|}
\hline \multicolumn{4}{|c|}{ 5. Usia Anak } \\
\hline & a. $\quad 1-6$ & 34 & 59,6 \\
\hline & b. $7-12$ & 18 & 31,5 \\
\hline & c. $13-18$ & 5 & 8.77 \\
\hline \multicolumn{4}{|c|}{ Status sekolah } \\
\hline & a. belum sekolah & 31 & 54,3 \\
\hline & b. $\quad$ TK & 17 & 29,8 \\
\hline & SD & 7 & 12,2 \\
\hline & d. $\quad$ SMP & 2 & 3,5 \\
\hline \multicolumn{4}{|c|}{ 7. Pekerjaan Ibu } \\
\hline & a. IRT & 35 & 61,4 \\
\hline & b. Bekerja & 22 & 38,6 \\
\hline
\end{tabular}

Berdasarkan tabel 4.1 di atas dapat diketahui bahwa karakteristik ibu sebagian besar berada pada tingkat pendidikan SMA, berusia 20-30 tahun, sebagai ibu rumah tangga, dan memiliki penghasilan keluarga sebesar 2-3 juta. Karakteristik anak dapat terlihat sebagian besar jenis kelamin perempuan, berusia 1-6 tahun, dan sebagian besar belum bersekolah.

\section{Tingkat Pengetahuan Responden}

Tabel 2. Gambaran Skor Tingkat Pengetahuan Orang tua Tentang Faktor Risiko di Jakarta Timur Tahun $2018(n=57)$

\begin{tabular}{lcccc}
\hline Variabel & Jumlah & $\begin{array}{c}\text { Presentase } \\
(\%)\end{array}$ & Min & Max \\
\hline $\begin{array}{l}\text { Skor 76- } \\
100 \text { (Baik) }\end{array}$ & 23 & 40,35 & 45 & 100 \\
$\begin{array}{l}\text { Skor 50- } \\
75\end{array}$ & 33 & 57,89 & & \\
$\begin{array}{l}\text { (Cukup) } \\
\text { Skor <50 } \\
\text { (Kurang) }\end{array}$ & 11 & 19,29 & & \\
\end{tabular}

Berdasarkan tabel 4.2 di atas dapat diketahui bahwa orang tua yang memiliki skor 76-100 sebanyak 40,35 $\%$, skor $50-75$ sebanyak $57,89 \%$, dan skor kurang dari 50 sebanyak 19,29 $\%$. Skor minimal adal 45 dan skor maksimal adalah 100. Tabel di atas menjelaskan bahwa sebagian besar orang tua memiliki tingkat pengetahuan cukup mengenai faktor risiko kanker pada anak.

\section{Korelasi Karakteristik Responden dengan Tingkat Pengetahuan}

Tabel 3. Hubungan Karakteristik Pendidikan Terakhir Penghasilan Keluarga, Usialbu, Jenis Kelamin, Kelas, dan Pekerjaan Ibu dengan Tingkat Pengetahuan, di Jakarta Timur Tahun 2018 $(\mathrm{n}=57)$

\begin{tabular}{lcc}
\hline \multicolumn{1}{c}{ Variabel } & $\mathrm{r}$ & Pvalue \\
\hline 1. Pendidikan Ibu & 0,034 & 0,04 \\
2. Penghasilan Keluarga & 0,12 & 0,36 \\
3. Usia Ibu & 0,146 & 0,09 \\
4. Pekerjaan & 0,256 & 0,307 \\
5. Usia Anak & 0,097 & 0,98 \\
6. Riwayat Kanker & 0,175 & 0,433
\end{tabular}




\section{Pembahasan}

Hasil penelitian menunjukkan sebagian besar tingkat pengetahuan orang tua tentang faktor risiko kanker pada anak memiliki tingkat pengetahuan cukup $(57,89 \%)$. Tingkat pengetahuan seseorang tentu akan berbeda-beda bergantung dari banyak aspek. Tingkat pengetahuan dapat dipengaruhi oleh faktor usia, pendidikan, pemanfaatan media massa, sosial budaya, pengalaman dan lingkungan (Erfandi, 2009).

Berdasarkan analisis bivariat untuk mengetahui korelasi antara dua variabel, diketahui karakteristik pendidikan orang tua memiliki hubungan positif dan kuat terhadap tingkat pengetahuan (pvalue 0,04). Hal ini menunjukkan semakin tinggi pendidikan ibu, maka akan semakin baik pula pengetahuan tentang faktor risiko kanker pada anak. Hasil penelitian tersebut sejalan dengan penelitian yang dilakukan oleh Corneles dan Losu (2015) melibatkan responden ibu hamil, diketahui bahwa hubungan tingkat pendidikan dengan pengetahuan ibu hamil tentang kehamilan memiliki pvalue $<0,05$. Seseorang dengan tingkat pendidikan yang tinggi umumnya memiliki wawasan luas dan rasa keingintahuan yang besar sehingga banyak mempelajari hal-hal terkait kesehatan. Pendidikan tinggi juga turut mempengaruhi peningkatan akses teknologi informasi. Saat ini, pengetahuan seputar kesehatan dapat diakses melalui internet, media sosial, dan e-book. Pernyataan tersebut sejalan dengan penelitian yang dilakukan oleh Pradono dan Sulistyowati (2014) bahwa semakin tinggi tingkat pendidikan seseorang akan lebih intens mencari sumber informasi melalui televisi, internet, dan surat kabar secara cetak maupun elektronik. Hal ini memungkinkan seseorang untuk meningkatkan pemahamannya terhadap sesuatu peristiwa atau kondisi.

\section{Simpulan}

Karakteristik responden (ibu) adalah sebagian besar berada pada tingkat pendidikan SMA, berusia 20-30 tahun, sebagai ibu rumah tangga, dan memiliki penghasilan keluarga sebesar 2-3 juta. Karakteristik anak dapat terlihat sebagian besar jenis kelamin perempuan, berusia 1-6 tahun, dan sebagian besar belum bersekolah. Tingkat pengetahuan sebagian besar orang tua tentang faktor risiko kanker pada anak 
tergolong cukup. Terdapat hubungan positif dan kuat antara pendidikan ibu dengan pengetahuan mengenai faktor risiko kanker pada anak.

\section{Saran}

Orang tua hendaknya menambah wawasan mengenai penyakit kanker pada anak dengan banyak membaca buku kesehatan, browsing internet, dan memanfaatkan informasi kesehatan seputar kanker dari media massa. Orang yang telah memliki pengetahuan yang cukup baik, hendaknya melakukan upaya pencegahan terhadap penyakit kanker pada anak.

\section{Daftar Pustaka}

American cancer society (2016). Risk factor and cause of childhood cancer. Diunduh pada 10 April 2018 dari https://www.cancer.org/cancer/ cancer-in-children/risk-factorsand-causes.html

Erfandi (2009). Definisi pengetahuan serta faktor yang mempengaruhinya. $\mathrm{http} \cdot /$ referensiparamedis/definis i-pengetahuan-serta-faktor-html. Diunduh pada 28 Agustus 2018 Kemenkes RI. (2013). Riset Kesehatan Dasar 2013. diunduh pada 10 April 2018 dari www.depkes.go.id

Manarisip, M. (2015). Gambaran gangguan radiasi handphone terhadap kesehatan siswa kelas
XI SMK Discovery Manado. Jurnal Kedokteran Komunitas dan Tropik: Vol. III, Nomor 3, Juli.

Murphy SL, Xu J, Kochanek KD. (2013). Deaths: Final Data for 2010. National Vital Statistics Reports. Vol 61. No. 4. Hyattsville, MD: National Center for Health Statistics

National Cancer Institute (2015). Research on Screening and Early Detection Is Critical to Progress against Cancer. diunduh pada 9 Maret 2018 dari https://www.cancer.gov/research /areas/screeningdated

Notoatmojo. (2012). Pengantar Pendidikan Kesehatan Dan Ilmu Perilaku Kesehatan.

Yogyakarta: Andi offset.

Stefan, D.C \& Harif, M. (2017). Early warning signs and diagnostic approach in childhood. Pediatric Cancer in Africa. Doi. 101007978331917938

Potts, N.L., \& Mandleco, B.L. (2012). Pediatric nursing: caring for children and their families. 3rd edition. USA: Delmar Cengage Learning

Pradono, J. Sulistyowati, N. (2013). Hubungan Antara Tingkat Pendidikan, pengetahuan tentang kesehatan lingkungan, perilaku hidup sehat dengan status kesehatan. Buletin Penelitian Sistem Kesehatan. ISSN: 2088270

Setiyawan, D. (2017). Waspadai kanker pada anak. diunduh pda 10 April 2018 dari 
http://www.kpai.go.id/berita/wasp adai-kanker-pada-anak/

Tehuteru, E. S. (2015). Mewaspadai gejala kanker pada anak. Buletin Jendela Data dan Informasi

Kesehatan, ISSN: 2088-270

Ward, E., DeSantia, C., Robbins, A., Kohler, B., \&Jemal. (2014).

Childhood and adolescent cancer statistics, 2014. Cancer Journal for Clinicians, 64, 2, 83-101. Doi.10.3322/caac.21219

Wariyah, C. \& Dewi, S.H.C (2013). Penggunaan pengawet dan pemanis buatan pada pangan jajanan anak sekolah (PJAS) di wilayah Kabupaten Kulon ProgoDIY. Agritech, Vol. 33, No. 2. 